\title{
Anthelmintic efficacy of Cratylia argentea (Desv.) Kuntze against the gastrointestinal nematodes of sheep
}

\section{Eficácia anti-helmíntica de Cratylia argentea (Desv.) Kuntze contra nematódeos gastrintestinais de ovinos}

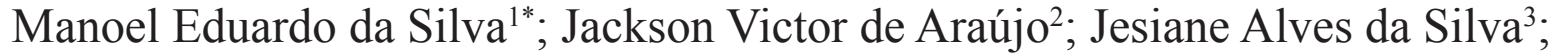 \\ Lorendane Millena de Carvalho ${ }^{4}$; Evangelista das Chagas ${ }^{5}$; Raul Rio Ribeiro ${ }^{6}$
}

\begin{abstract}
The use of natural products having therapeutic properties can be considered an alternative approach for the control of helminths in ruminants, reducing the indiscriminate use of chemicals as well as production costs. The anthelmintic effectiveness of Cratylia argentea on sheep endoparasites was evaluated both in vitro by assessing the number of third-stage larvae recovered per gram of feces (LPG) from coprocultures treated with pods/ground seeds, macerated leaves or vermiculite (control), and in vivo using the Fecal Egg Count Reduction Test (FECRT) in two groups of lambs ( $\mathrm{n}=8$ /group) that received $1 \mathrm{~mL} \mathrm{~kg}^{-1}$ body weight of $C$. argentea solution (treated group) or distilled water (control group) orally. When compared to control group, there was a significant reduction in the percentage of LPG in the leaves group $(55.88 \% ; \mathrm{p} \leq 0.05)$ and pods/ground seeds group $(82.48 \% ; \mathrm{p} \leq 0.01)$. There was no significant reduction $(\mathrm{p}>0.05)$ in the average count of EPG upon treatment with the aqueous solution of $C$. argentea. These findings suggest that $C$. argentea extract mainly obtained from pods/ground seeds has a promising potential for the control of young stages of gastrointestinal nematodes. However, further studies are needed to validate the use of $C$. argentea as an alternative method for the control of parasitic diseases of ruminants.
\end{abstract}

Key words: Cratylia sp. Anthelmintic effectiveness. Gastrointestinal Helminths. Small Ruminants.

\section{Resumo}

$\mathrm{O}$ uso de produtos naturais com propriedades terapêuticas pode ser considerado uma abordagem alternativa no controle de helmintos em ruminantes, reduzindo o uso indiscriminado de produtos químicos, bem como os custos de produção. A eficácia anti-helmíntica de Cratylia argentea sobre endoparasitos de ovinos foi avaliada tanto in vitro, mediante teste de recuperação de larvas infectantes por grama de fezes (LPG) a partir de coproculturas tratadas com vagens/sementes trituradas, folhas maceradas e vermiculita (controle), como in vivo, por meio de Teste de Redução da Contagem de Ovos por Grama de Fezes (TRCOF) em dois grupos de borregas $(n=8 /$ grupo) que receberem por via oral

${ }^{1}$ Prof. Pesquisador, Empresa de Pesquisa Agropecuária de Minas Gerais, EPAMIG, Instituto Técnico de Agropecuária e Cooperativismo, ITAC, Campo Experimental de Pitangui, CEPI, Zona Rural, Pitangui, MG, Brasil. E-mail: manoelsilva@ epamig.br

2 Prof. Titular, Universidade Federal de Viçosa, DVT/UFV, Viçosa, MG, Brasil. E-mail: jvictor@ufv.br

${ }^{3}$ Discente, Engenharia Agronômica, Universidade Federal de São João del-Rei, DCA/UFSJ, Sete Lagoas, MG, Brasil. E-mail: jesiane_silva@yahoo.com.br

${ }^{4}$ Discente, Programa de Pós-Graduação em Medicina Veterinária, DVT/UFV, Viçosa, MG, Brasil. E-mail: lorendane@gmail.com

5 Técnico Agrícola, Empresa de Pesquisa Agropecuária de Minas Gerais, CEPI/EPAMIG, Pitangui, MG, Brasil. E-mail: evagelistadaschagas@gmail.com

${ }^{6}$ Prof. Associado, Departamento de Medicina Veterinária, Universidade Federal de Juiz de Fora, UFJF, Juiz de Fora, MG, Brasil. E-mail: raul.rio@ufjf.edu.br

* Author for correspondence 
$1 \mathrm{~mL} \mathrm{~kg}^{-1} \mathrm{PV}$ de solução de C. argentea (grupo tratado) ou água destilada (grupo controle). Quando comparado ao grupo controle, houve redução estatisticamente significativa na porcentagem de LPG a partir do grupo tratado com folhas $(55,88 \% ; \mathrm{p} \leq 0,05)$ e do grupo tratado com vagens/sementes $(82,48 \%$; $p \leq 0,01)$. Não houve redução significativa $(p>0,05)$ na contagem média de OPG após o tratamento com a solução aquosa de $C$. argentea. Essas descobertas sugerem que o extrato de $C$. argentea obtido principalmente a partir de vagens/sementes tem potencial promissor para o controle de estágios jovens de nematódeos gastrointestinais. Contudo, são necessários novos estudos, a fim de validar o uso desta planta como um método alternativo no controle das parasitoses de ruminantes.

Palavras-chave: Cratylia sp. Ação anti-helmíntica. Helmintos gastrintestinais. Pequenos Ruminantes.

\section{Introduction}

Parasitic infections caused by gastrointestinal nematodes represent an important pathological threat worldwide, affecting extensive pasture-based livestock regimes, the use of which is widespread (HOSTE et al., 2015) and resulting in productive losses of ruminants in all breeding regions (ALEGRÍA-LOPEZ et al., 2015).

To date, alternatives for helminth control and prevention are based exclusively on the use of antiparasitic agents with little technical support, leading to an unsustainable management scenario. The selection of resistant isolates, impact on food safety, public health, and the risk of environmental contamination by the available expensive anthelmintic residues, and the unavailability of some products in certain geographic regions require a strong commitment to explore new approaches in the integrated management of these infections, warranting alternative measures for the control of the gastrointestinal parasitic diseases (YOSHIHARA et al., 2013; HOSTE et al., 2015).

The use of natural products having therapeutic properties to treat parasitism and to improve the productive performance of animals is ancient (CUNHA et al., 2014). Phytotherapy is the treatment of diseases through fresh vegetables, plant drugs or plant extracts, and is considered as a promising treatment approach, where the environmental impact can be minimized, thus reducing the cost of production and administering the active components in the form of pasture (CHAGAS, 2008; MOLENTO, 2009; VILLALBA et al., 2014). However, the same criteria that are recommended for the use of synthetic chemicals should be followed in the case of phytotherapy to avoid the selection of resistant isolates (ALMEIDA, 2013). Moreover, the use of nutraceuticals has increased the product variety, and offered equivalent therapeutic options, cost effectiveness, and targeted actions in comparison to the commercial drugs, with therapeutic indications complementary to the existing medications (LAPA et al., 2004).

Plant species rich in tannins, catechin tannins, catechins, steroids, flavonoids, xanthones, and saponins have a promising potential in the control of gastrointestinal nematodes, and may even have a synergistic effect among the involved metabolites. Hence, studies focusing on their scientific validation prior to their use are indispensable. Acceptance of the plant-derived drugs and phytotherapy in the clinical field can be accomplished only if these products meet the criteria of efficacy, safety, and quality control compared to the synthetic products. In short, the products derived from plants must be evaluated and confirmed, along with ensuring that its administration to living organisms is safe (RATES, 2001).

The use of plants rich in condensed tannins can be considered as an alternative approach for the control of helminths in sheep, reducing the indiscriminate use of chemicals as well as production costs (NIEZEN et al., 1995). In addition to herd improvement, the use of condensed tannin sources in the animals' diet may decrease the selection pressure on the gastrointestinal nematodes. The action of these condensed tannins can be exerted 
directly against a population of gastrointestinal nematodes by severely affecting the biological processes of the nematodes (HOSTE et al., 2006), or indirectly by improving the host's protein utilization and consequently generating a better immune response against the parasites (BUTTER et al., 2000; STRAIN; STEAR, 2001). However, the exact mechanism of the action of the condensed tannins is uncertain and might differ depending on the parasite and its stage of development in the plant (MIN; HART, 2003).

For the sustainable management of animal production, it is preferable to use plant species selected naturally by the ruminants (MORAISCOSTA et al., 2014). The legume Cratylia argentea is a perennial, shrub, and is a native plant of the Cerrado region of Brazil, and is adapted to the acidic soils with drought-resistant properties (ARGEL et al., 2000). In Brazil, C. argentea is found in the North and the Northeast regions; however, it is more prevalent in the Cerrado region of the CentralWest (RAMOS et al., 2003), where it is used as a protein bank for small ruminants and in the parasite management.

The objective of this study was to evaluate the anthelmintic activity of $C$. argentea on the gastrointestinal nematodes of sheep by means of a Fecal Egg Count Reduction Test (FECRT) (in vivo) and Test of Number of Third-Stage Larvae (L3) Recovered per Gram of Feces (LPG) (in vitro).

\section{Material and Methods}

\section{Biosafety and Ethics in Animal Use}

All animal handling procedures were carried out in accordance with the Ethical Principles of Animal Experimentation adopted by the Brazilian College of Veterinary Medicine and the Brazilian College of Animal Experimentation - COBEA. The whole procedure was approved by the Committee on Ethics in the Use of Animals of the Agricultural Research Company of Minas Gerais (EPAMIG), under Protocol Number 04/2016.

\section{Test $A$ - in vivo Test}

Evaluation of the anthelmintic activity of $C$. argentea was conducted at the Experimental Pitangui Field (CEPI), belonging to the Agricultural Research Company of Minas Gerais (EPAMIG), located at $19^{\circ} 40^{\prime} 58^{\prime \prime}$ south latitude and $44^{\circ} 53^{\prime} 25^{\prime \prime}$ west longitude, at an altitude of $709 \mathrm{~m}$ in the municipality of Pitangui-MG in the summer season $(12 / 11 / 16$ to $12 / 23 / 16)$, with a recorded accumulated rainfall of $194.25 \mathrm{~mm}$. Sixteen ewe lambs (Santa Ines $x$ Texel crossbred) were reared on a slatted and suspended floor, with age and average live weight of 56 days and $19.37 \mathrm{~kg}$, respectively, and were stratified by weight and randomly assigned to two equivalent groups: GI (Treated) and GII (Control). The inclusion criterion was based on the previous absence of infection by gastrointestinal nematodes, which was confirmed by the Egg Count per Gram of Feces (EPG) according to the method of Gordon and Whitlock (1939), with few modifications. During the 42-day experimental period, all the animals (GI and GII) were kept in the pastures predominantly composed of grasses belonging to Brachiaria decumbens species, which were naturally contaminated by the eggs and nematode larvae at a stocking rate of $7 \mathrm{AU}$ hectare ${ }^{-1}$. The animals were collected in the afternoon from the covered sheepfold until the following morning, when each of them received $300 \mathrm{~g}$ of the concentrate produced on the farm daily, with $18 \%$ crude protein and $80 \%$ of total digestible nutrients (TDN). GI (Treated) animals were administered $1 \mathrm{~mL} \mathrm{~kg}^{-1}$ body weight (BW) of C. argentea solution orally each day except on weekends. The $C$. argentea solution was prepared by the aqueous extraction of $500 \mathrm{~g}$ of leaves crushed in an industrial blender in $3 \mathrm{~L}$ of water, followed by conventional plastic sieve filtration and storage at 4 ${ }^{\circ} \mathrm{C}$ until use. The animals of the GII group (Control) received equivalent experimental volumes of distilled water $\left(1 \mathrm{~mL} \mathrm{~kg}^{-1} \mathrm{BW}\right)$ orally. Both groups were monitored continuously on a daily basis by a veterinarian to identify any clinical and/or behavioral changes suggestive of treatment-related 
adverse reactions. The animals were weighed and individual fecal samples were collected directly from the rectal ampulla for TRCOF analyses every 14 days. The data recorded were expressed as mean values.

Assay $B$ - in vitro Test

After thirty days of completion of the Test A in vivo Test and to evaluate the effect of different fractions of $C$. argentea on intermediate stages of endoparasites, a total pool of feces weighing 180

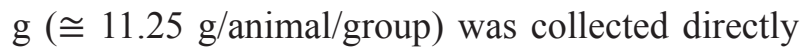
from the rectal ampulla of the GI and GII animals. This fecal content with EPG of 1200 eggs was subdivided into three portions of equal weight $(60 \mathrm{~g}$ portion $\left.^{-1}\right)$, which were then added to equal portions [60 g (1: 1)] of different fractions of $C$. argentea: 1) Pods/ Ground Seeds; 2) Macerated Leaves; 3) Vermiculite (Control). Then, the total content of each treatment $(120 \mathrm{~g})$ was subdivided into 6 parts, each of which was placed in a disposable plastic cup, and then moistened and kept in a greenhouse for seven days, followed by the LPG analysis using the Baermann technique.

\section{Statistical analyzes}

According to the nature of the data (raw or mean), analysis of variance (ANOVA) test was used to compare the mean values of EPG (Assay A - in vivo Test) and recovered LPG (Assay $\mathrm{B}$ - in vitro Test), followed by Tukey's multiple comparison using the BioEstat 4 software (AYRES et al., 2005). A significance level of $95 \%$ was applied in all statistical tests.

\section{Results and Discussion}

The use of plants as an alternative to conventional therapeutics is increasing in recent time, as is research on the analysis of bioactive compounds that can be used for the above said purpose (SANDOVAL-CASTRO et al., 2012). Such increase in the research interest can be understood by the increase in the number of drug resistant microorganisms during conventional treatments (RIBEIRO, 2008; PADILHA et al., 2010). In Brazil, the use of plants for the treatment of various diseases is widespread in the human population. However, such use of plants is often done in an artisanal and empirical manner, which warrants further studies on the active components, mechanism of action on the body, therapeutic efficacy, and safety during use.

Significant in vitro efficacy $(p \leq 0.05)$ of macerated leaves and pods/ground seeds of $C$. argentea after seven days of treatment with sheep feces in coprocultures could be explained by the presence of specific compounds in the plant, which interfere with the egg hatchability and/or larval development of nematodes (Table 1). In this context, Von Son-de Fernex et al. (2012) reported the presence of phenolic compounds and tannins in three $C$. argentea ecotypes; $C$. argentea, $C$. argentea Yacapani, and $C$. argentea Veranera that inhibited the complete dehorning and migration of Haemonchus contortus larvae. In addition, Menezes et al. (1991) observed that crushed seeds of $C$. floribunda at the concentrations of 50, 300, and $500 \mathrm{mg} 10^{-1} \mathrm{~g}$ of feces in co-cultures inhibited the hatchability of $H$. contortus eggs from goats at 15.5 , 64.9, and $99.9 \%$, respectively. However, the same authors reported that dehydrated crushed leaves were ineffective in inhibiting the egg hatchability. 
Table 1. Mean number, standard deviation $(\sigma)$ and the percentage reduction of infective larvae (L3) per gram of feces (LPG) of sheep recovered by the Baermann method after 7 days of coproculture with different fractions of Cratylia argentea.

\begin{tabular}{lcc}
\hline \multicolumn{1}{c}{ Treatments } & $\mathrm{L}_{3}$ Recovered $\pm \sigma$ & Reduction (\%) \\
\hline Pods/Seeds & $60.0^{\mathrm{b}} \pm 51.2$ & -82.48 \\
Macerated Leaves & $151.1^{\mathrm{b}} \pm 125.1$ & -55.88 \\
Vermiculite (Control) & $342.5^{\mathrm{a}} \pm 160.9$ & 0 \\
\hline
\end{tabular}

Different lowercase letters in the lines mean significant statistical difference $(p<0.05$; Tukey's test).

The anthelmintic action of aqueous extract of $C$. argentea was evaluated in the present study. Minho (2006) reported the effectiveness of the Acacia mearnsii (black acacia) extract in the reduction of EPG and the parasite load of $H$. contortus. The condensed tannins extracted from this plant were able to reduce the elimination of eggs in the feces and the parasitic load in the animals (MAX, 2010). In addition, upon infecting $H$. contortus in sheep, Martinez-Ortiz-de-Montellano et al. (2010) reported the reduction of female fecundity and the elimination of eggs in the feces after treatment with Lysiloma latisiliquum plant extract. However, unlike $A$. mearnsii, the use of $L$. latisiliquum was not effective in reducing the parasitic load in sheep. In this study, administration of aqueous solution of $C$. argentea did not significantly reduce the mean EPG count, although a reduction of up to $57.14 \%$ $(p=0.65)$ of the EPG count was recorded (Table 2). However, it might be worthwhile to validate new experiments that evaluate different doses of treatment with different formulations of $C$. argentea at shorter intervals of coproparasitological evaluation (7 days), which might demonstrate promising results. The complete absence of side effects supports the possibility of the use of this formulation as a new treatment protocol for gastrointestinal nematodes in sheep with a solution of $C$. argentea (Table 3). Alonso-Diaz et al. (2010) reported that it is necessary to define several aspects such as the part of the plant, age, physiological state, aspects related to extraction and adequate dose. Factors related to the animal (species, age, physiological state) should also be considered for nematode control. It is important to note that both the beneficial effects and the deleterious effects of tannins depend on many factors, mainly the concentration and structure of these compounds (HOSTE et al., 2006).

The use of condensed tannins can be configured as an auxiliary control approach, concomitantly with traditional parasitic control to reduce the usage of conventional anthelmintic drugs. Implementation of such a combinational approach can minimize the evolution of multidrug resistance against anti-helminthic drugs, along with prolonging the efficacy of the drugs currently being used and for future use. Therefore, the study of bioactive compounds and the development of an anthelmintic product containing condensed tannin can have great commercial potential (YOSHIHARA et al., 2013). 
Table 2. Mean number of Egg Count per Gram of Feces (EPG) and standard deviation ( $\sigma$ ) quantified by the McMaster technique in sheep feces treated with Cratylia argentea extract and the percentage of average egg reduction at days $0,14,28$ and 42 days after treatment.

\begin{tabular}{cccc}
\hline \multirow{2}{*}{ Time } & \multicolumn{2}{c}{ Experimental Groups } & $\begin{array}{c}\text { Reduction } \\
(\%)\end{array}$ \\
\cline { 2 - 4 }$($ Day $)$ & $\begin{array}{c}\text { Control } \\
( \pm \sigma)\end{array}$ & $\begin{array}{c}\text { Treated } \\
( \pm \sigma)\end{array}$ & 0 \\
\hline 0 & $0.00^{\mathrm{a}}(0.00)$ & $0.00^{\mathrm{a}}(0.00)$ & 0 \\
+14 & $0.00^{\mathrm{a}}(0.00)$ & $0.00^{\mathrm{a}}(0.00)$ & -57.14 \\
+28 & $87.50^{\mathrm{a}}( \pm 99.10)$ & $37.50^{\mathrm{a}}( \pm 106.07)$ & -10.46 \\
+42 & $1,075.00^{\mathrm{a}}( \pm 962.01)$ & $962.50^{\mathrm{a}}( \pm 717.01)$ & \\
\hline
\end{tabular}

Different lowercase letters in the lines mean significant statistical difference $(\mathrm{p}<0.05$; Tukey's test).

Table 3. Mean body weight (BW) and standard deviation $(\sigma)$ of lambs treated with aqueous solution of Cratylia argentea $\left(1 \mathrm{~mL} \mathrm{~kg}^{-1} \mathrm{BW}\right)$ (treated) and normal saline (control) at times $0,14,28$ and 42 days after treatment.

\begin{tabular}{ccc}
\hline \multirow{2}{*}{ Time } & \multicolumn{3}{c}{ Experimental Groups } \\
\cline { 2 - 3 }$($ Day $)$ & Control & Treated \\
& $\mathrm{kg}( \pm \sigma)$ & $\mathrm{kg}( \pm \sigma)$ \\
\hline 0 & $20.00^{\mathrm{a}}( \pm 2.51)$ & $18.75^{\mathrm{a}}( \pm 5.82)$ \\
+14 & $20.75^{\mathrm{a}}( \pm 3.15)$ & $20.50^{\mathrm{a}}( \pm 5.90)$ \\
+28 & $23.55^{\mathrm{a}}( \pm 2.55)$ & $21.63^{\mathrm{a}}( \pm 5.13)$ \\
+42 & $26.63^{\mathrm{a}}( \pm 2.33)$ & $25.38^{\mathrm{a}}( \pm 5.40)$ \\
\hline
\end{tabular}

Different lowercase letters in the lines mean significant statistical difference $(p<0.05$; Tukey's test).

\section{Conclusions}

C. argentea extract obtained from mainly pods/ ground seeds depicts a promising potential for the control of the intermediate stages of gastrointestinal nematodes. However, more studies are required to elucidate the active components present in various parts of the $C$. argentea, effective extraction methods, new therapeutic protocols, and formulations for the recommended use of this plant as an alternative control agent for checking the spread of parasitic diseases in ruminants.

\section{Acknowledgement}

The authors are grateful to the National Council for Scientific and Technological Development (CNPq), the State of Minas Gerais Research Foundation (FAPEMIG), the Minas Gerais
Agricultural Research Company (EPAMIG), and the Federal University of Juiz de Fora UFJF) for providing logistical and financial support.

\section{References}

ALEGRÍA-LÓPEZ, M. A.; RODRÍGUEZ-VIVAS, R. I.; TORRES-ACOSTA, J. F. J.; OJEDA-CHI, M. M.; ROSADO-AGUILAR, J. A. Use of ivermectin as endoparasiticide in tropical cattle herds generates resistance in gastrointestinal nematodes and the tick Rhipicephalus microplus (Acari: Ixodidae). Journal of Medical Entomology, Oxford, v. 52, n. 2, p. 214-221, 2015.

ALMEIDA, L. R. Manejo de parasitoses em sistema orgânico de produção de leite. Arquivo Instituto Biológico, São Paulo, v. 80, n. 1, p. 129-134, 2013.

ALONSO-DÍAZ, M. A.; TORRES-ACOSTA, J. F. J.; SANDOVAL-CASTRO, C. A.; HOSTE, H. Tannins and tropical tree fodders fed to small ruminants: a friendly foe? Small Ruminant Research, Amsterdam, v. 89, n. 2-3, p. 164-173, 2010. 
ARGEL, P. J.; DI PALMA, M. L.; ROMERO, F.; GONZÁLEZ, J.; LASCANO, C. E.; KERRIDGE, P. C.; HOLMANN, F. Silage of Cratylia argentea as dry-season feeding alternative in Costa Rica. In: FAO ELECTRONIC CONFERENCE ON TROPICAL SILAGE, 1., 1999, Rome. Proceedings... Rome: FAO, 2000. p. 65-67.

AYRES, M.; AYRES, J. R. M.; AYRES, D. L.; SANTOS, A. S. Aplicações estatísticas nas áreas de ciências biológicas e médicas. Belém: Sociedade Civil Mamirauá; MCT: Ed. Imprensa Oficial do Estado do Pará, 2005. 324 p.

BUTTER, N. L.; DAWSON, J. M.; WAKELIN, D.; BUTTERY, P. J. Effect of dietary tannin and protein concentration on nematode infection (Trichostrongylus colubriformis) in lambs. Journal of Agricultural Science, Cambridge, v. 134, n. 1, p. 89-99, 2000.

CHAGAS, A. C. S. Fitoterapia como alternativa no controle de verminose em caprinos e ovinos. In: VERÍSSIMO, C. J. (Coord.). Alternativas de controle da verminose em pequenos ruminantes. Nova Odessa: Instituto de Zootecnia, 2008. p. 75-79.

CUNHA, M. P. V.; ALVES NETO, A. F.; SUFFREDINI, I. B.; ABEL, L. J. C. Avaliação da atividade anti-helmíntica de extratos brutos de plantas da Floresta Amazônica e Mata Atlântica brasileira sobre Haemonchus contortus. Arquivo Brasileiro de Medicina Veterinária e Zootecnia, Belo Horizonte, v. 66, n. 2, p. 374-380, 2014.

GORDON, H. M.; WHITLOCK, H. V. A new technique for counting nematode eggs in sheep faeces. Journal of Council of Science and Industry Research, Melbourne, v. 12, n. 1, p. 50-52, 1939.

HOSTE, H.; JACKSON, F.; ATHANASIADOU, S.; THAMSBORG, S. M.; HOSKIN, S. O. The effects of tannin-rich plants on parasitic nematodes in ruminants. Trends in Parasitology, Oxford, v. 22, n. 6, p. 253-261, 2006.

HOSTE, H.; TORRES-ACOSTA, J. F. J.; SANDOVALCASTRO, C. A.; MUELLER-HARVEY, I.; SOTIRAKI, S.; LOUVANDINI, H.; THAMSBORG,S. M.; TERRILL, T. H. Tannin containing legumes as a model for nutraceuticals against digestive parasites in livestock. Veterinary Parasitology, Amsterdam, v. 212, n. 1-2, p. 5-17, 2015.

LAPA, A. J.; SOUCCAR, C.; LIMA, L. M. T. R.; GORDINHO, R. O. M. L. Farmacologia e toxicologia de produtos naturais. 5. ed. Porto Alegre: UFSC; Florianópolis: UFRGS, 2004. p. 247-262.
MARTÍNEZ-ORTIZ-DE-MONTELLANO, C.; VARGAS-MAGAÑA， J. J.; CANUL-KU， H. I.; MIRANDA-SOBERANIS, R.; CAPETILLO-LEAL, C.; SANDOVAL-CASTRO, C. A.; HOSTE, H.; TORRES-ACOSTA, J. F. J. Effect of a tropical tanninrich plant Lysiloma latisiliquum on adult populations of Haemonchus contortus in sheep. Veterinary Parasitology, Amsterdam, v. 172, n. 3-4, p. 283-290, 2010.

MAX, R. A. Effect of repeated wattle tannin drench on worm burdens, fecal egg counts and egg hatchability naturally acquired nematode infections in sheep and goats. Veterinary Parasitology, Amsterdam, v. 169, n. 1-2, p. 138-143, 2010.

MENEZES, R. C. A. A.; VIEIRA, L da S.; CAVALCANTE, A. C. R.; CAVADA, B. S.; OLIVEIRA, J. T. A.; MOREIRA, R. A. Estudos preliminares "in vitro" da atividade ovicida de folhas e sementes de quatro leguminosas sobre Haemonchus contortus de caprinos. Revista Brasileira de Parasitologia Veterinária, Jaboticabal, v. 1, p. 37, 1991.

MIN, B. R.; HART, S. P. Tannin for suppression of internal parasites. Journal of Animal Science, Albany, v. 81 , n. 14, p. 102-109, 2003. Supplement 2.

MINHO, A. P. Efeito anti-helmíntico de taninos condensados sobre nematódeos gastrintestinais em ovinos. 2006. Tese (Doutorado em Ciências) - Centro de Energia Nuclear na Agricultura. Universidade de São Paulo, Piracicaba.

MOLENTO, M. B. Parasite control in the age of drug resistance and changing agricultural practices. Veterinary Parasitology, Amsterdam, v. 163, n. 3, p. 229-234, 2009.

MORAIS-COSTA, F.; VASCONCELOS, V. O.; DUARTE, E. R.; LIMA, W. S. Plants from cerrado for the control of gastrointestinal nematodes of ruminants In: QUICK, W. Anthelmintics: clinical pharmacology, uses in veterinary medicine and efficacy. New York: Nova Biomedical, 2014. p. 90-107.

NIEZEN, J. H.; WAGHORN, T. S.; CHARLESTON, W. A. G.; WAGHORN, G. C. Growth and gastrointestinal parasitism in lambs grazing either lucerne (Mendicato sativa) or sulla (Hedysarum coronarium) which contains condensed tannins. Journal of Agricultural Science, Cambridge, v. 125, n. 2, p. 281-289, 1995.

PADILHA, M. M.; VILELA, F. C.; ROCHA, C. Q.; DIAS, M. J.; SORCINI, R; SANTOS, M. H.; ALVES DA SILVA, G.; GIUSTI-PAIVA, A. Anti-inflammatory properties of Morus nigra leaves. Phytotherapy Research, London, v. 24, n. 10, p. 1496-1500, 2010. 
RAMOS, A. K. B; SOUZA, M. A de; PIZARRO, E. A. Algumas informações sobre a produção e o armazenamento de sementes de Cratylia argêntea. Planaltina: Embrapa Cerrados, 2003. 4 p. (Embrapa Cerrados. Circular Técnica, 25).

RATES, S. M. K. Plants as source of drugs. Toxicon, Oxford, v. 39, n. 5, p. 603-613, 2001.

RIBEIRO, J. L. Manejo da cultura do girassol no MeioNorte do Brasil. Teresina: Embrapa Meio-Norte, 2008. 9 p. (Embrapa Meio-Norte. Circular técnica, 48).

SANDOVAL-CASTRO, C. A.; TORRES-ACOSTAA, J. F. J.; HOSTEB, H.; SALEMD, A. Z. M.; CHANPÉREZ, J. I. Using plant bioactive materials to control gastrointestinal tract helminths in livestock. Animal Feed Science and Technology, Amsterdam, v. 176, n. 1-4, p.192-201, 2012.

STRAIN, S. A. J.; STEAR, M. J. The influence of protein supplementation on the immune response to Haemonchus contortus. Parasite Immunology, Oxford, v. 23, n. 10, p. 527-531, 2001.
VILLALBA，J. J.; MILLER，J., UNGAR， E. D.; LANDAU, S. Y.; GLENDINNING, J. Ruminant selfmedication against gastrointestinal nematodes: evidence, mechanism, and origins. Parasite, Paris, v. 21, n. 31, p. 1-10, 2014.

VON SON-DE FERNEX, E.; ALONSO-DIAZ, M. A.; VALLES-DE LA MORA, B.; CAPETILLO-LEAL, C. M. In vitro anthelmintic activity of five tropical legumes on the exsheathment and motility of Haemonchus contortus infective larvae. Experimental Parasitology, New York, v. 131, n. 4, p. 413-418, 2012.

YOSHIHARA, E.; MINHO, A. P.; YAMAMURA, M. H. Efeito anti-helmíntico de taninos condensados em nematódeos gastrintestinais de ovinos (Ovis aries). Semina: Ciências Agrárias, Londrina, v. 34, n. 6, p. 3935-3950, 2013. Supplement 2. 